\title{
腰部神経根ブロック側臥位刺入法の経験
}

$$
\begin{aligned}
& \text { 豊 田 耕一郎* 椎 木 栄 一* 栗 山龍太郎* } \\
& \text { 藤澤武慶* 末 冨 裕* 田中 浩* }
\end{aligned}
$$

\section{Lateral Method for Nerve Root Block}

Koichiro Toyoda*, Eiichi Shiigi*, Ryutaro Kuriyama*, Takenori Fujisawa*, Yutaka Suedomi*, and Hiroshi Tanaka*

腰部神経根ブロックを側臥位で試行した症例を検討して報告する。対象は神経根ブロック 337 例中 13 例である。男性 11 例，女性 2 例と男性に多く，平均年齢 65 才である。全例腰椎椎間板ヘルニアで，治療 は手術 10 例, 保存的 3 例であった。側卧位で行った理由は腹臥位，斜位困難が 13 例全例であったが， MRI 撮像困難が 6 例で，上位外側へルニアが多かった。治療前 JOA スコアは 12 点で最終 24 点であっ た。 JOABPEQ は治療前疼痛関連障害が 16 , 腰椎機能障害が 33 , 歩行機能障害が 13 , 社会生活障害が 25, 心理的障害が 45 で，最終でそれぞれ 75，78，59，53，53 と心理的障害以外は改善効果が高かった。 40 歳以上の腹臥位で根ブロック可能なへルニア手術例（17 例）との比較では JOABPEQ の歩行機能障 害のみ側臥位法症例が有意に低かった。

We report our experience in nerve root block using the lateral approach in 13 out of 337 cases (11 males, two females), whose average age was 65 . Of the 13 , ten underwent surgical therapy. The lateral approach was used because patients could not maintain prone and oblique positions. Many had lateral disc herniation. Only the walking disability score of JOABPEQ differed significantly between the lateral and prone approaches. Nerve root block with the lateral approach is useful for upper lumbar lateral disc herniation in patients who are unable to maintain prone and oblique positions due to lumbar disc disease.

Key words : nerve root block (神経根ブロック), lumbar disc herniation (腰椎椎間板ヘルニア)

\section{は じめ に}

腰部神経根ブロックの刺入方法には腹臥位刺入法と 斜位刺入法がおこなわれているが，稀に疼痛高度のた めに体位の保持が困難な症例を経験する。今回これま でに経験した腰部神経根ブロックを側臥位で試行した 症例（側臥位刺入法とする）を検討したので報告する.

\section{対 象}

対象は 2005.4-2010.3 までに施行した神経根ブロッ ク 337 例（543 根）中 13 例（4\%）であり，男性 11 例, 女性 2 例と男性に多く，平均年齢 65才（47-83） と中高年に多かった。平均経過観察期間は 9 か月 （2-24）である. 症例の内訳は腰椎椎間板ヘルニア
が 13 例で脊柱管内 7 例（中心性 2 , 脱出 3 例), 椎 管孔内外 6 例であり, 罹患椎間は L $2 / 3: 2$ 例, L3/4 : 1 例, L4/5： 9 例, L5/S : 1 例, 罹患神経根は L2 根 : 1 例, L3 根: 2 例, L4 根: 5 例, L5 根: 5 例であっ た. 治療は手術 10 例（骨形成的両側 1 片側 6), 保存 的 3 例であった。

\section{方法}

循環器用X線透視装置（TOSHIBA Infinix）を使 用し，患側上の側臥位で透視下に前後像を見ながら消 毒, 局麻後 Nerve root infiltration でブロックを行 う（図 1)。造影剂は以前はイソビスト 240 であった が，使用停止になったため最近はオムニパーク 240 を $1-1.5 \mathrm{ml}$ を使い, 局所麻酔薬は $1 \%$ リドカイン

\footnotetext{
* 山口県立総合医療センター整形外科 Department of Orthopedic Surgery, Yamaguchi Grand Medical Center, Yamaguchi, Japan
} 

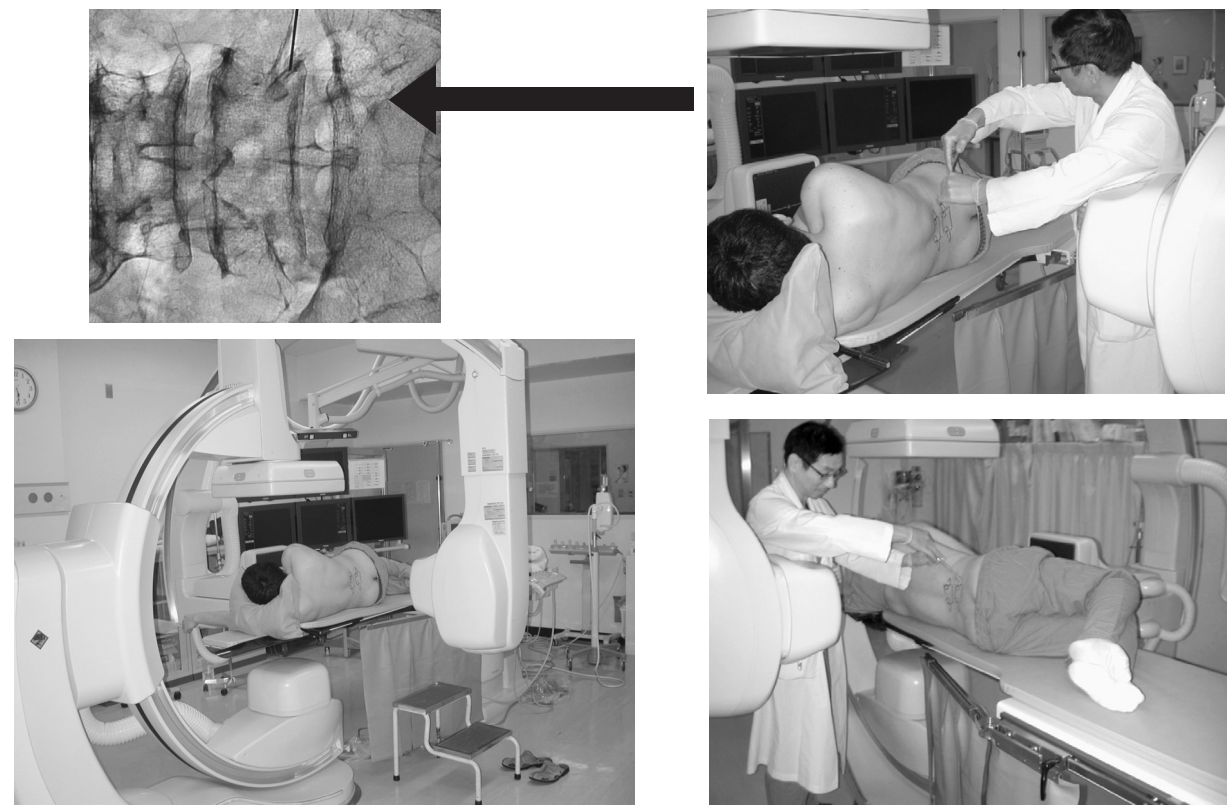

図 1 側臥位根ブロックの方法

1 〜 $1.5 \mathrm{ml}$ を使用する.

検討項目として患者背景（罹病期間，受診方法，受 診前診断)，側臥位法で行った理由，治療成績評価 (JOA, VAS, RDQ (Rolland Morris Disability Questionaire), JOABPEQ (JOA Back Pain Evaluation Questionnaire) ) ${ }^{1)}$ を行い，腹臥位根ブロッ クが可能な手術症例との比較検討も併せて行った。

\section{結果}

患者背景であるが，罹病期間は平均 38 日，救急外 来受診例は 3 例，紹介患者は 7 例，歩行困難を 11 例 に認めた。確定診断までの診断は LDH 10 例, LCS 3 例であり, MRI 撮像は 4 例に行われていたにあ関わ らず外側ヘルニアという診断がついていなかった。

側臥位で神経根ブロックを行った理由は腹臥位，斜 位困難が 13 例全例であったが，MRI 撮像困難が 6 例 で仰臥位困難 6 例である. L5 根症 5 例で 中心性へル ニア（L45） 2 例で，外側ヘルニア 2 例であった.

MRI 撮像可能であった 7 例は 根ブロック試行目的 で行ったが，外側ヘルニア例が 5 例であった。治療前 JOA スコアは 11.5 点, 腰痛 VAS は 5.7, 下肢痛 VAS は 8.5，下肢しびれは 6.4，RDQ は 20 で，下肢 痛 VAS が高かった。治療後 $1 \mathrm{M}$ の JOA，腰痛下肢痛
下肢しびれ VAS，RDQ は 21.4，1.1，1.2，1.1，8 と 改善し最終もほぼ良好であった。JOABPEQ は治療 前疼痛関連障害が 16 , 腰椎機能障害が 28 , 歩行機能 障害が 4 , 社会生活障害が 24 ，心理的障害が 46 で, 疼痛, 腰椎機能, 歩行機能, 社会生活機能障害が高度 であったが，最終でそれぞれ 75，78，59，53，53 と 心理的障害以外は 20 点以上で有意に改善した. 40 歳 以上の腹臥位で根ブロック可能なへルニア手術例（17 例）との比較では 3 ヶ月後の VAS下肢痛，6r月後 の VAS しびれ，JOABPEQ の歩行機能障害のみ側臥 位法症例が有意に低く, 歩行困難が特徵で下肢痛, し びれの改善に時間を要した（表 1 ）.

$$
\text { 考察 }
$$

腰部神経根ブロックの目的は診断 としての罹患神 経根の同定や 治療としての 疼痛の改善, さらにブ ロック効果期間で手術適応を決定する手段としても用 いられる 2)3) が，通常は MRI（ミエロ, CTM）検 查後に行う。側臥位刺入法の適応としては, 神経根ブ ロックの際に腹臥位, 斜位困難な症例であり, 上位 神経根障害, 外側ヘルニア, 脱出・中心性ヘルニアが 対象になるが，仰臥位保持困難のために MRI 撮像困 難な根症状症例には，問診，神経学的所見を可能な限 


\begin{tabular}{|c|c|c|}
\hline & 腹臥位（N=17） & 側臥位（N=13） \\
\hline 年齢（才） & 59 & 65 \\
\hline 罹病期間（日） & 53 & 35 \\
\hline JOA & 12 & 8 \\
\hline $\mathrm{RDQ}$ & 16 & 20 \\
\hline VAS 腰痛 & 5.8 & 5.7 \\
\hline 下肢痛 & 8.5 & 8.5 \\
\hline 3M 下肢痛 & 0.5 & $1.9 ※$ \\
\hline 下肢しびれ & 6.8 & 6.4 \\
\hline 6M 下肢しびれ & 0.9 & $2.5 \%$ \\
\hline JOABPEQ 疼痛機能障害 & 24 & 16 \\
\hline 腰椎機能障害 & 34 & 33 \\
\hline 歩行機能障害 & 32 & $13 ※$ \\
\hline 社会生活障害 & 27 & 21 \\
\hline \multirow[t]{2}{*}{ 心理的障害 } & 31 & 44 \\
\hline & \multicolumn{2}{|c|}{$(※: \mathrm{P}<0.01$, Mann-Whitney U) } \\
\hline
\end{tabular}

り詳細にとり，側臥位で CT 撮像して軟部条件を撮像 後, 神経根レベルを絞れれば積極的に同日に側臥位で の根ブロックを行い, MRI を撮像している.

\section{ま と め}

1.腰部神経根ブロック側臥位刺入法の経験した。

2. 3370 例中 13 例 $(4 \%)$ で，外側ヘルニア 6 ，中 心性ヘルニア 2 , 上位根 8 例であった.

3.手術を 10 例 $(77 \%)$ に施行した。

4. 神経根ブロックの際に腹臥位（斜位）困難，仰臥 位で MRI 撮像困難な症例に有用であった。

5. 腹臥位可能手術例と比較では術後 3 力月下肢痛,
6M 下肢しびれ VAS，JOABPEQ 治療前歩行機能 障害のみ 有意差を認めた。

\section{参 考 文 献}

1) Fukui, M., et al. : JOA back pain evaluation questionnaire: initial report. J. Orthop. Sci., 12 : 443-450, 2007.

2）金子和生, 田口敏彦:【腰痛に対する各種保存治療 私 はこうしている ブロック療法】腰椎变性疾患に対する 神経根・椎間関節ブロック. 日本腰痛学会雑誌, 12(1)： 72-76, 2006.

3）田口敏彦, 他：【腰部脊柱管狭窄(症)】画像診断とその 限界 腰部脊柱管狭窄症に対する神経根ブロック・造影 検査. NEW MOOK 整形外科, 9：105-109, 2001. 